\title{
Pengaruh Zakat, Islamic Corporate Social Responsibility dan Penerapan Good Governance Bisnis Syariah terhadap Reputasi dan Kinerja Bank Umum Syariah di Indonesia
}

\author{
Syurmita, Miranda Junisar Fircarina \\ Program Studi Akuntansi, Fakultas Ekonomi dan Bisnis, Universitas Al Azhar Indonesia, \\ Jl. Sisingamangaraja, Jakarta, 12110
}

Penulis untuk korespondensi/E-mail: syurmita@uai.ac.id

\begin{abstract}
Abstrak - Penelitian ini bertujuan untuk menguji pengaruh Zakat, Islamic Corporate Social Responsibility (ICSR) dan Good Governance Bisnis Syariah (GGBS) terhadap Reputasi dan Kinerja Bank Umum Syariah di Indonesia. Penelitian dilakukan terhadap Bank umum syariah yang tercatat di Otoritas Jasa Keuangan(OJK). Teknik analisis data menggunakan uji analisis regresi linear berganda. Berdasarkan hasil penelitian diketahui bahwa zakat berpengaruh positif signifikan terhadap kinerja perusahaan, namun tidak berpengaruh signifikan terhadap reputasi perusahaan. Islamic Corporate Social Responsibility (ICSR) berpengaruh positif signifikan terhadap reputasi dan kinerja perusahaan, namun pengaruh Good Governance Bisnis Syariah (GGBS) terhadap reputasi dan kinerja perusahaan tidak ditemukan dalam penelitian ini.
\end{abstract}

Abstract - This study aims to examine the effect of Zakat, Islamic Corporate Social Responsibility (ICSR) and Good Governance Business Sharia (GGBS) on the Reputation and Performance of Sharia Commercial Banks in Indonesia. The study was conducted on Islamic commercial banks registered at the Financial Services Authority (OJK). Data analysis techniques using multiple linear regression analysis. Data obtained from annual reports of Islamic banks published on the official website of each company. The results show that zakat has a significant positive effect on company performance, but does not have a significant effect on the company's reputation. Islamic Corporate Social Responsibility (ICSR) has a significant positive effect on company reputation and performance, however but the effect of Good Corporate Syariah Business (GGBS) on company reputation and performance is not found in this study.

Keywords - Zakat, Islamic Corporate Social Responsibility (ICSR), Good Governance Business Sharia (GGBS), Reputation, Performance.

\section{PENDAHULUAN}

$\mathrm{P}$ erekonomian syariah saat ini sedang menjadi isu yang menarik untuk diperbincangkan salah satunya adalah mengenai bank syariah. Perkembangan bank syariah memang belum pesat jika dibandingkan dengan bank konvensional, tetapi perkembangan bank syariah dari tahun 2014 sampai dengan Juni 2019 cukup besar, hal ini dapat dilihat dari jumlah aset yang dimiliki oleh perbankan syariah. Berdasarkan data statistik perbankan syariah yang dikeluarkan oleh Otoritas Jasa
Keuangan (OJK), bank umum syariah per Juni 2019 berjumlah 14 dan memiliki aset sebesar 499,34 trilliun rupiah.

Perkembangan aset yang ditunjukkan oleh bank syariah, belum bisa menyatakan bahwa bank syariah lebih unggul dibandingkan bank konvensional. Hal ini dikarenakan adanya keterbatasan supply dan akses akan produk keuangan syariah, rendahnya tingkat utilitas dan literasi keuangan syariah, perlunya optimalisasi pengawasan dari pemangku kepentingan serta kebijakan yang selaras dengan perkembangan 
bank syariah. Dengan memperhatikan masalah tersebut, zakat, ICSR, dan GGBS bisa menjadi salah satu cara untuk mewujudkan industri perbankan syariah yang tumbuh dan berkelanjutan serta memberikan kontribusi bagi perekonomian nasional demi menuju Indonesia sebagai pusat keuangan syariah dunia.

Zakat merupakan salah satu cara perusahaan berkontribusi dalam perekonomian untuk mengurangi kemiskinan. UU No. 23 tahun 2011 tentang pengelolaan zakat menyebutkan dalam pasal 1 ayat (2) bahwa zakat adalah harta yang wajib dikeluarkan oleh seorang muslim atau badan usaha untuk diberikan kepada yang berhak menerimanya sesuai dengan syariat islam. Zakat yang dikeluarkan oleh badan usaha biasa disebut zakat perusahaan. Zakat perusahaan merupakan zakat yang dibayarkan perusahaan dari total laba yang dihasilkan.

Islamic Corporate Social Responsibility (ICSR) merupakan konsep CSR yang dikembangkan dari konsep CSR konvensional. Corporate Social Responsibility (CSR) merupakan proses untuk mengkomunikasikan dampak sosial dan lingkungan dari kegiatan ekonomi organisasi terhadap kelompok khusus yang berkepentingan dan terhadap masyarakat secara keseluruhan. Tanggung jawab sosial perusahaan itu sendiri dapat digambarkan sebagai ketersediaan informasi keuangan dan non-keuangan berkaitan dengan interaksi organisasi dengan lingkungan fisik dan lingkungan sosialnya, yang dapat dibuat dalam laporan tahunan perusahaan atau laporan sosial terpisah (Guthrie dan Mathews, 1985 dalam Wardani, 2015).

Selain Zakat dan ICSR, penerapan Good Governance Bisnis Syariah (GGBS) menjadi komponen yang penting bagi lembaga keuangan khususnya bank syariah. GGBS merupakan pedoman bagi bank umum syariah untuk menjalankan usahanya secara sehat dan sesuai dengan prinsip-prinsip syariah. Pelaksanaan GGBS ini tetap mengacu pada aspek- aspek GCG dan menambahkan aspek syariah yaitu spiritual (halalan dan thoyyiba) dan operasional (akuntabilitas, fairness, transparency, tanggungjawab, dan independensi sesuai dengan Al-Quran dan Hadist. Untuk memperkuat pelaksanaan GGBS, KNKG (Komisi Nasional Kebijakan Governance) menetapkan pedoman tentang pelaksanaan good corporate bisnis syariah tahun 2011. Dengan menerapkan
GGBS, keberlangsungan bisnis bank syariah akan lebih terjamin untuk memberikan manfaat dan tanggung jawab kepada masyarakat maupun kepada pemilik kepentingan (Stakeholder). Oleh sebab itu, Good Governance Bisnis Syariah menjadi hal yang penting dan mungkin berpengaruh terhadap kinerja dan reputasi perusahaan.

Dari beberapa hasil penelitian terdahulu, peneliti tertarik untuk menguji pengaruh zakat, ICSR dan penerapan GGBS terhadap kinerja dan reputasi perusahaan. Alasan peneliti ingin menguji ulang variabel zakat, ICSR, dan GGBS karena pertama, peneliti menggabungkan ketiga variabel yang sebelumnya belum pernah diteliti secara bersamaan dan ingin mengetahui apakah ada pengaruh dan hubungan antar ketiga variabel tersebut dengan reputasi dan kinerja. Kedua, peneliti ingin mengetahui lebih lanjut apakah bank syariah di Indonesia sudah menerapkan prinsip-prinsip Good governanace bisnis syariah atau belum. Dan yang terakhir adalah untuk memberikan kontribusi akademis dan melengkapi literatur tentang zakat, ICSR dan penerapan GGBS.

\section{TINJAUAN PUSTAKA}

\section{Teori Agency}

Teori keagenan mendeskripsikan hubungan antara pemegang saham (shareholders) sebagai principal dan manajemen sebagai agen. Manajemen harus mempertanggungjawabkan semua pekerjaannya kepada pemegang saham yang sudah dirumuskan di dalam sebuah kontrak. Teori agensi berhubungan dengan faktor yang memengaruhi Islamic Corporate Social Responsibility (ICSR), dimana di dalam ICSR terdapat tanggung jawab principal kepada agent untuk mengembangkan perekonomian dan meningkatkan kualitas hidup masyarakat. ICSR juga merupakan bentuk tanggung jawab sosial akibat dari aktivitas operasional perusahaan.

Dalam penelitian ini, kepemilikan institusional dalam suatu perusahaan memiliki peranan yang cukup penting untuk meminimalisasi terjadinya agency problem antara manajemen dengan pemegang saham. Keberadaan kepemilikan institusional dianggap mampu melakukan pengawasan yang efektif dalam setiap pengambilan keputusan. Teori agency juga menjadi dasar bagi perusahaan untuk tidak 
melupakan tanggung jawabnya kepada agent maupun pemegang saham, karena dengan perusahaan memberikan tanggung jawabnya maka reputasi perusahaan secara otomatis menjadi baik.

\section{Sharia Enterprice Theory (SET)}

Sharia Enterprice Theory (SET) digunakan untuk memahami pemangku kepentingan perusahaan dari perspektif islam. Teori ini menyatakan bahwa stakeholder perusahaan meliputi tidak hanya manusia, tetapi juga lingkungan alam, dan Tuhan. Manusia akhirnya bertanggungjawab kepada Allah untuk semua aktivitas mereka di dunia (Triyuwono, 2007). Dari uraian tersebut, dapat disimpulkan bahwa Shariah Enterprise Theory mendukung adanya Islamic Corporate Social Responsibility yang memang sesuai syariah islam dan juga mendukung adanya pembayaran zakat oleh perbankan syariah yang memang merupakan kewajiban bagi muslim. ICSR dan pembayaran zakat, dalam perspektif teori ini merupakan bentuk pertanggungjawaban manusia atas semua yang telah diberikan oleh Tuhan, agar kelak manusia dapat kembali kepada Tuhannya dalam keadaan fitrah sesuai dengan arti zakat yang bersih. Hal ini dikarenakan tujuan dari zakat adalah memberikan harta yang didalamnya terdapat hak orang lain.

\section{Teori Legitimasi}

Teori legitimasi juga merupakan salah satu teori yang mendasari pengungkapan Islamic Corporate Social Responsibility (ICSR). Dalam penelitian ini, teori legitimasi dapat digunakan untuk menjelaskan keterkaitan dewan komisaris, dewan pengawas syariah, dan profitabilitas dengan ICSR agar regulasi dari Bank Indonesia terpenuhi serta menjalankan fungsi bank syariah yang mengupayakan kesejahteraan ekonomi bagi masyarakat. Legitimasi juga berhubungan dengan zakat, karena dengan adanya zakat yang diberikan oleh perusahaan terhadap masyarakat tentunya akan berdampak terhadap pembentukan image perusahaan itu sendiri yang dapat berpengaruh terhadap profitabilitas perusahaan nantinya (Kurniawan \& Suliyanto, 2013).

\section{Zakat dan Reputasi}

Zakat adalah harta yang wajib dikeluarkan apabila telah memenuhi syarat-syarat yang telah ditentukan dan disalurkan kepada orang yang membutuhkan. Zakat yang dikeluarkan oleh perusahaan bukan hanya bertujuan untuk memengaruhi kewajiban saja, tetapi juga sebagai bentuk tanggung jawab kepada masyarakat yang nantinya akan memengaruhi reputasi perusahaan.

Berdasarkan Sharia Enterprise Theory, zakat yang dibayarkan oleh perusahaan bisa dijadikan sebagai bentuk realisasi kewajiban perusahaan dalam perspektif islam. Teori sharia enterprise theory mendukung penelitian dari Sidik dan Reskino (2016) yang menyatakan bahwa Zakat memiliki pengaruh yang positif dan signifikan terhadap reputasi perusahaan.

Berdasarkan teori dan penelitian terdahulu, peneliti juga beranggapan bahwa pembayaran zakat yang dilakukan oleh perusahaan bukan hanya untuk memenuhi kewajiban rukun Islam, tetapi zakat juga sebagai bentuk untuk mensejahterakan masyarakat, yang pada akhirnya perusahaan mendapatkan citra yang baik dimata konsumen dan pemegang saham. Oleh karena itu, dapat dirumuskan hipotesis sebagai berikut:

\section{$H_{1}$ : Zakat berpengaruh terhadap reputasi.}

\section{Zakat dan Kinerja}

Pembayaran zakat yang dilakukan oleh perusahaan bergantung pada jumlah laba perusaaan. Laba yang dihasilkan tentunya akan memengaruhi kinerja perusahaan, karena manajemen akan selalu berusaha untuk memberikan laba yang baik. Kinerja perusahaan adalah suatu hasil perusahaan yang dipengaruhi oleh kegiatan operasioanl perusahaan dalam memanfaatkan sumber daya yang dimiliki.

Teori agensi mengarah pada hubungan agensi, pemilik (principal) yang memberi mandat pada pekerja (agent). Jika hubungan antara pemilik dan agent baik, maka dapat menghasilkan kinerja yang baik. Hal ini mendukung hasil penelitian dari Sidik dan Reskino (2016) menyatakan bahwa reputasi perusahaan yang baik akan menjaga likuiditas modal perusahaan dan meningkatkan kinerja karyawan, yang mana hal tersebut akan berdampak pula pada kinerja perusahaan.

Peneliti juga beranggapan bahwa zakat berpengaruh terhadap kinerja perusahaan atau kinerja keuangan karena jika perusahaan ingin membayar zakatnya dengan jumlah yang baik, 
maka secara tidak langsung perusahaan akan memaksimalkan penjualan dan manajemennya untuk mendapatkan likuiditas modal dan laba yang baik. Maka dapat dirumuskan hipotesis sebagai berikut:

\section{$\mathrm{H}_{2}$ : Zakat berpengaruh terhadap kinerja $\mathrm{ROE}$ perusahaan.}

\section{$H_{3}$ : Zakat berpengaruh terhadap kinerja NOM perusahaan}

\section{Islamic Corporate Social Responsibility dan Reputasi}

Islamic Corporate Social Responsibility (ICSR) merupakan salah satu hal yang penting diperhatikan oleh perusahaan karena sebagai bentuk tanggung jawab kepada masyarakat yang tidak hanya memperhatikan perusahaan dan perekonomian tetapi juga memperhatikan keadilan sosial, lingkungan yang berlandaskan pada hukum Islam, yang pada akhirnya dapat meningkatkan reputasi perusahaan. Hal ini didukung dengan agency Theory yang menyatakan bahwa manajemen harus mempertanggung jawabkan semua pekerjaannya kepada pemegang saham yang sudah dirumuskan di dalam sebuah kontrak dan mempertanggungjawabkannya kepada agent (pekerja). Hal ini sejalan dengan hasil penelitian yang dilakukan oleh Wardani (2015), Sidik dan Reskino (2016) yang menyatakan bahwa ICSR pada Bank Syariah berpengaruh positif secara signifikan terhadap Reputasi.

Peneliti juga beranggapan bahwa, ICSR dapat berpengaruh yang signifikan terhadap reputasi karena ketika perusahaan memberikan tanggung jawabnya kepada pemegang kepentingan dan masyarakat, maka akan timbul penilaian yang baik kepada perusahaan. Tanggung jawab yang diberikan oleh perusahaan tentunya sangat diharapkan oleh masyarakat terutama di lingkungan perusahaan. Oleh sebab itu, ICSR dapat berpengaruh signifikan terhadap reputasi perusahaan. Berdasarkan penjelasan diatas, maka hipotesis yang diajukan adalah:

$H_{4}$ : Islamic Corporate Social Responsibility berpengaruh terhadap reputasi perusahaan.

\section{Islamic Corporate Social Responsibility dan Kinerja}

Teori stakeholder mengemukakan bahwa ketika perusahaan bertemu dengan berbagai macam harapan para stakeholder mereka akan lebih mampu menciptakan kinerja perusahaan yang luar biasa (Freeman, 1984). Menurut Rivai dan Basri (2004), Kinerja perusahaan adalah hasil kerja yang dapat dicapai oleh seseorang atau kelompok orang dalam suatu perusahaan sesuai dengan wewenang dan tanggung jawab masingmasing dalam upaya pencapaian tujuan perusahaan secara legal, tidak melanggar hukum dan tidak bertentangan dengan moral dan etika. Tanggung jawab yang diberikan oleh perusahaan ini ditunjukkan melalui program corporate social responsibilitynya.

Peneliti beranggapan bahwa ketika perusahaan ada kepentingan dan tanggung jawab kepada para stakeholder, maka akan ada kinerja perusahaan yang sangat baik, karena secara tidak langsung ICSR juga merupakan pencapain terbesar perusahaan yang harus dipenuhi. Oleh karena itu, dapat dirumuskan hipotesis sebagai berikut:

$H_{5}$ : Islamic Corporate Social Responsibility (ICSR) berpengaruh terhadap kinerja ROE perusahaan.

$H_{6}$ : Islamic Corporate Social Responsibility (ICSR) berpengaruh terhadap kinerja NOM perusahaan.

\section{Good Governance Bisnis Syariah dan Reputasi \\ Good Governance Bisnis Syariah (GGBS)} merupakan sistem yang mengatur, mengelola, dan mengawasi proses pengelolaan usaha untuk melancarkan hubungan antar manajemen, pemegang saham, dan pihak lainnnya yang berkepentingan, tujuannya untuk menciptakan nilai tambah bagi perusahaan. Jika bank syariah telah memenuhi indikator Good Governance Bisnis Syariah, maka nasabah maupun pemegang saham dapat beranggapan bahwa perusahaan dalam kondisi baik yang pada akhirnya reputasi perusahaan pun meningkat.

Pratiwi (2016) menemukan bahwa kualitas penerapan GCG pada bank syariah sudah termasuk kategori baik karena indikatornya telah sesuai dengan peraturan No. 11/33/PBI/2009 mengenai pelaksanaan Good Corporate Governance bagi Bank Umum Syariah. GGBS yang baik akan menghasilkan reputasi perusahaan baik. Good Governance Bisnis Syariah dapat menjadi alat untuk 
meningkatkan kinerja perusahaan. GGBS ini penting untuk perusahaan syariah, karena dengan banyaknya peraturan yang dibuat oleh perusahaan dan dewan pengawas syariah, maka perusahaan akan lebih mudah menerapkan peraturan yang ada.

\section{$H_{7}$ : Good Governance Bisnis Syariah} berpengaruh terhadap reputasi perusahaan

Good Governance Bisnis Syariah dan Kinerja GGBS merupakan sistem yang menjadi acuan dalam berbisnis secara Islami, baik untuk lembaga yang sudah menyatakan diri sebagai entitas syariah maupun yang belum. Salah satu indikator penilaian Good Governance Bisnis Syariah (GGBS) lkan reputasi yang baik bagi perusahaanadalah struktur dan manajemen dari dewan direksi, karyawan, dan dewan pengawas serta nilai perusahaan. GGBS yang baik, akan menimbu tetapi belum tentu dapat memengaruhi kinerja perusahaan.

Hal ini mendukung hasil penelitian Wirman (2011), yang menyatakan bahwa Good Governance Bisnis Syariah (GGBS) memiliki pengaruh yang kuat terhadap kinerja perusahaan karena indeks yang digunakan dalam pemenuhan kriteria syariah dilihat dari operasional berusahaan bukan dalam menghasilkan laba.

Peneliti juga beranggapan bahwa pelaksanaan Good Governance bisnis syariah akan memengaruhi kinerja perusahaan secara langsung, karena GGBS merupakan sebuah penduan untuk menjalankan operasional untuk menghasilkan laba perusahaan. Oleh karena itu, berdasarkan penjelasan diatas hipotesis yang diajukan adalah:

$H_{8}$ : Good Governance Bisnis Syariah (GGBS) berpengaruh signifikan terhadap kinerja ROE perusaahaan.

$H_{9}$ : Good Governance Bisnis Syariah (GGBS) berpengaruh signifikan terhadap kinerja NOM perusahaan.

\section{METODE PENELITIAN}

\section{Populasi, Sampel, dan Data Penelitian}

Populasi dalam penelitian ini adalah Bank Umum Syariah di Indonesia. Metode pemilihan sampel dalam penelitian ini adalah purposive judgement sampling. Adapun kriteria yang digunakan dalam penentuan sampel penelitian ini adalah bank umum syariah yang berturutturut terdaftar di Otoritas Jasa Keuangan (OJK) pada kurun waktu penelitian yaitu tahun 20142018, menerbitkan laporan keuangan tahunan yang dipublikasikan tahun 2014-2018 di situs resmi perusahaan dan data laporan keuangan yang dibutuhkan untuk menghitung variabel penelitian. Atas dasar kriteria tersebut di peroleh jumlah sampel sebanyak 8 bank umum syariah.

Data yang digunakan dalam penelitian ini adalah data sekunder. Sumber data yang digunakan dalam penelitian ini yaitu laporan tahunan Bank Umum Syariah dalam kurun waktu yaitu tahun 2014-2018 yang diakses melalui website resmi masing-masing perusahaan.

\section{Metode Analisis Data}

Metode analisis yang digunakan dalam penelitian ini adalah analisis regresi berganda. Dengan persamaan regresi yang digunakan untuk menguji hipotesis adalah :

$$
Y=a+b_{1} X_{1}+b_{2} X_{2}+b_{3} X_{3}+e
$$

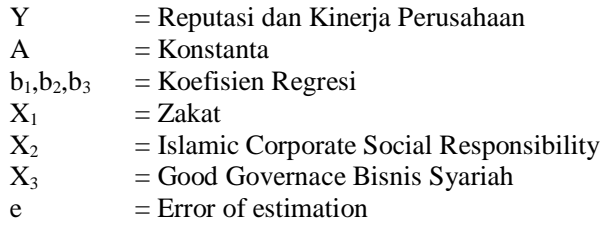

Alat analisis ini digunakan karena sesuai dengan rumusan masalah dan tujuan penelitian yaitu ingin menguji pengaruh beberapa variabel independen terhadap variabel dependen. Software yang digunakan dalam menganalisis data dalam penelitian ini adalah aplikasi SPSS 20 untuk pengujian terhadap data sampel dari setiap variabel. Pengujian-pengujian yang akan dilakukan dalam penelitian ini yaitu:

1. Uji Validitas dan Reliabilitas Instrumen

2. Uji statistik destkritif,

3. Uji asumsi klasik, yang terdiri dari uji normalitas, heteroskedastisitas, dan multikolinearitas

4. Uji Koefisien Determinasi $\left(\mathrm{R}^{2}\right)$

5. Uji Parsial ( $t$ test)

6. Uji Simultan (f test)

\section{Operasionalisasi Variabel}

$\underline{\text { Reputasi Perusahaan }}$ 
Reputasi perusahaan merupakan persepsi konsumen mengenai kemampuan perusahaan dalam memberikan pelayanan. Untuk mengukur seberapa baik reputasi perusahaan, dalam penelitian ini reputasi di ukur dengan menggunakan market share yaitu Dana Pihak Ketiga (DPK) yang dikelola oleh bank syariah. DPK dapat merepresentasikan tingkat kepercayaan masyarakat untuk menempatkan dananya diantara bank syariah yang ada. Reputasi diukur dengan rumus berikut:

$$
\begin{aligned}
& \text { REP } \\
& =\frac{\text { Dana Pihak Ketiga Bank }}{\text { Total Dana Pihak Ketiga di Pasar }}
\end{aligned}
$$

\section{Kinerja Perusahaan}

Kinerja merupakan hasil akhir yang akan dicapai oleh perusahaan. Kinerja diproyeksikan dengan return on equity (ROE) dan net operation margin (NOM). Rasio Retrun on Equity (ROE) merupakan indikator yang amat penting bagi para pemegang saham dan calon investor untuk mengukur kemampuan bank dalam memperoleh laba bersih yang dikaitkan dengan pembayaran deviden. ROE diukur dengan rumus berikut:

$$
\begin{aligned}
& R O E \\
& =\frac{\text { Laba sebelum zakat dan pajak } t}{\text { Total Ekuitas }}
\end{aligned}
$$

Net Operatinng Margin (NOM) adalah rasio yang menggambarkan pendapatan operasional bersih sehingga diketahui kemampuan rata-rata aktiva produktif dalam menghasilkan laba. NOM diukur dengan cara sebagai berikut:

$\frac{(\text { Pendapatan Operasional }-D B H)-\text { Beban Operasional }}{\text { Rata }- \text { Rata Aktiva Produktif }}$

\section{Zakat}

$$
\text { Rata-Rata Aktiva Produktif }
$$

Zakat diukur dengan menggunakan data zakat yang dibayarkan perusahaan, yang umumnya pada bank syariah zakat perusahaan telah diungkapkan pada laporan laba rugi. Zakat dihitung pada porsi $2,5 \%$ denan rumus sebagai berikut:

\section{Zakat}

$=2,5 \% \times$ Laba sebelum pajak tahun berjalan

\section{Islamic Corporate Social Responsibility (ICSR)}

ICSR diukur dengan menggunakan analisis konten. Identifikasi jenis pengungkapan ICSR dengan cara membaca dan menganalisa laporan keuangan tahunan perusahaan. Item yang diungkapkan kemudian diakumulasikan dan dilihat persentase item yang diungkapkan dari keseluruhan item. Adapun tema pengungkapan ICSR dalam kerangka ISR (Othman et al.,2009) ada 6 tema, adalah keuangan dan investasi, produk dan jasa, karyawan, masyarakat, lingkungan dan tata kelola. Kemudian tahap penilaian menggunakan ketentuan nilai 1 jika ada pengungkapan terkait item dan 0 untuk sebaliknya. Indeks pengungkapan ICSR dihitung sebagai berikut:

ISR

$=\frac{\text { jumlah skor pengungkapan yang dipenuhi }}{\text { jumlah skor maksimum }}$

\section{Good Governance Bisnis Syariah (GGBS)}

Good Governance Bisnis Syariah ini diukur dengan indeks yang menunjukkan skor penerapan GGBS oleh lembaga bisnis syariah. Indeks tersebut disusun berdasarkan pedoman mengenai GGBS yang diatur oleh KNKG (2011). Pengukuran penerapan GGBS meliputi dari ketersediaan organ sesuai dengan prinsipprinsip GGBS dan bagaimana kinerja atas organ-organ tersebut.

Indeks Penerapan GGBS oleh bisnis Syariah di Indonesia terdiri dari 36 indikator. Untuk memudahkan pengukuran tigkat penerapan GGBS tersebut, peneliti memberikan skor 1 (satu) jika indikator yang dimaksud diungkap di dalam laporan tahunan, sementara jika tidak diungkap oleh bank syariah di dalam laporan tahunannya, peneliti memberikan skor 0 (nol). Indeks pengungkapan GGBS dihitung sebagai berikut :

$$
\begin{aligned}
& \text { GGBS } \\
& =\frac{\text { jumlah skor pengungkapan yang dipenuhi }}{\text { jumlah skor maksimum }}
\end{aligned}
$$

\section{HASIL DAN PEMBAHASAN}

\section{Deskripsi Objek Penelitian}

Populasi yang digunakan dalam penelitian ini adalah seluruh Bank Umum Syariah yang tercatatdi Otoritas Jasa Keuangan. Saat ini jumlah bank umum syariah yang tercatat sebanyak 14 Bank. Dari keempat belas bank umum Sariah, 8 bank diambil sebagai sampel penelitian. Teknik pengambilan sampel yang digunakan dalam penelitain adalah purposive sampling. Dari total 14 bank umum syariah, 
Bank Aceh Syariah, BPD Nusa Tenggara Barat Syariah, Bank Victoria Syariah, Bank Jabar Banten Syariah, Bank Panin Dubai Syariah, Maybank Syariah Indonesia tereliminasi karena tidak memenuhi kriteria purposive sampling. Deskripsi objek penelitian ditampilkan pada Tabel 1.

Tabel 1

Deskripsi Objek Penelitian

\begin{tabular}{|l|c|}
\hline & Jumlah \\
\hline Jumlah total bank umum syariah & 14 \\
\hline $\begin{array}{l}\text { Perusahaan yang tercatat secara berturut-turut dan menerbitkan laporan } \\
\text { keuangan dalam kurun wakku 2014-2018 }\end{array}$ & 12 \\
\hline Perusahaan Laba pada tahun berjalan & 8 \\
\hline Jumlah perusahaan yang dieliminasi & 6 \\
\hline Jumlah sampel perusahaan yang digunakan & 8 \\
\hline Periode penelitian (Tahun) & 5 \\
\hline Jumlah total Objek Penelitian & 40 \\
\hline
\end{tabular}

Sumber : Data yang diolah, 2020

\section{Analisis Statistik Deskriptif}

Hasil pengujian statistik deskriptif seluruh variabel penelitian ditampilkan pada Tabel 2 . Variabel Zakat diukur dengan mengalikan laba sebelum pajak tahun berjalan dengan porsi $2,5 \%$. Diketahui bahwa dari sampel penelitian, zakat tertinggi adalah PT Bank Tabungan Pensiunan Nasional Syariah (BTPNS) dan zakat terendah adalah PT Bank Syariah Bukopin (BSB). Rata-rata variabel zakat adalah 5700.32, dengan jumlah sampel sebanyak 40 perusahaan bank syariah.

Variabel Reputasi diukur dengan membandingkan dana pihak ketiga Bank dengan total dana pihak ketiga di pasar. Hasil pengujian statistik deskriptif terhadap 40 sampel laporan keuangan bank syariah di Indonesia menunjukkan nilai reputasi tertinggi adalah PT Bank Syariah Mandiri (BSM) dan reputasi terendah adalah PT Bank BCA Syariah (BCAS). Adapun nilai rata-rata reputasi sebesar 0,08 dan deviasi standar sebesar 0,84 .

Dalam penelitian ini, variabel kinerja perusahaan diukur dengan 2 (dua) proksi yaitu Return On Equity (ROE) dan Net Operating Margin (NOM). ROE diukur dengan membandingkan laba sebelum zakat dan pajak tahun berjalan dengan total ekuitas. Hasil pengujian statistik deskriptif menunjukkan bahwa PT Bank Tabungan Pensiunan Nasional Syariah (BTPNS) memiliki nilai ROE tertinggi dan PT. Bank Syariah Bukopin (BSB) mendapatkan nilai ROE terendah selama tahun 2014-2018.

Net Operating Margin diukur untuk menunjukkan kemampuan rata-rata aktiva produktif dalam menghasilkan laba. Hasil pengujian statistik terhadap 40 sampel perusahaan menunjukkan bahwa PT Bank Tabungan Pensiunan Nasional Syariah (BTPNS) tahun 2018 memiliki nilai Net Operating Margin tertinggi, dan PT.Bank Muamalat Indonesia (BMI) memiliki nilai Net Operating Margin terendah di tahun yang sama. Nilai rata-rata NOM untuk keseluruhan sampel adalah sebesar 0,02 dan deviasi standar sebesar 0,03 .

Tabel 2

Hasil Uji Statistik Deskriptif

\begin{tabular}{cccccc}
\hline Variable & $\mathrm{N}$ & Min & Max & Mean & Std.Dev \\
\hline Zakat & 40 & 33,00 & 32475 & 5700,32 & 7056,76 \\
ICSR & 40 & 0,350 & 0,790 & 0,563 & 0,123 \\
GGBS & 40 & 0,680 & 0,920 & 0,813 & 0,071 \\
Reputasi & 40 & 0,011 & 0,275 & 0,817 & 0,084 \\
ROE & 40 & 0,002 & 0,403 & 0,865 & 0,092 \\
NOM & 40 & 0,001 & 0,145 & 0,025 & 0,033 \\
\hline Sumber: Data yang diolah, 2020
\end{tabular}

\section{Analisis Regresi Linear Berganda}

Penelitian ini menggunakan 3 (tiga) model regresi linear berganda untuk menguji hipotesis. Model regresi pertama dilakukan untuk menguji pengaruh zakat, ICSR, GGBS terhadap reputasi perusahaan. Pengujian model pertama (I) menghasilkan persamaan regresi sebagai berikut:

$$
\mathrm{Y}=-0.046-0.005 \operatorname{Ln} \mathrm{Xl}+0.704 \mathrm{X} 2-0.285 \mathrm{X} 3+\varepsilon
$$

Keterangan:

Y: Reputasi Perusahaan

Ln_X1: Zakat

$\mathrm{X} 2$ : ICSR

X3: GGBS

$\varepsilon$ : Standard Error

Model regresi ke dua dilakukan untuk menguji pengaruh zakat, ICSR, GGBS terhadap kinerja Return On Equity (ROE). Pengujian model ke dua (II) menghasilkan persamaan regresi sebagai berikut:

$$
\mathrm{Y} 2=-8.015+0.868 \mathrm{Ln} \_\mathrm{X} 1-5.491 \mathrm{X} 2+1.641 \mathrm{X} 3+\varepsilon
$$

Keterangan:

Y: ROE

Ln_X1: Zakat

X2: ICSR

X3: GGBS

$\varepsilon$ : Standard Error 
Model regresi ke tiga dilakukan untuk menguji pengaruh zakat, ICSR, GGBS terhadap kinerja Net Operating Margin (NOM). Pengujian model ke tiga (III) menghasilkan persamaan regresi sebagai berikut:

$$
\mathrm{Y} 3=-0.065+0.013 \mathrm{Ln} \_\mathrm{X} 1-0.123 \mathrm{X} 2+0.060 \mathrm{X} 3+\varepsilon
$$

Keterangan:

Y: NOM

Ln_X1: Zakat

$\mathrm{X} 2$ : ICSR

X3: GGBS

E: Standard Error

Hasil uji statistik $\mathrm{t}$ yang digunakan untuk menganalis keenam hipotesis ditampilkan pada tabel 3 .

Tabel 3

Hasil Uji Statistik T

\begin{tabular}{cccc}
\multicolumn{4}{c}{ Hasil Uji Statistik T } \\
\hline Hipotesis & $\boldsymbol{\beta}$ & $\mathbf{t}$ & Sig. \\
\hline Zakat $\rightarrow$ Rep & $\mathbf{- 0 , 0 8 7}$ & $\mathbf{- 0 , 7 0 6}$ & $\mathbf{0 , 4 8 4}$ \\
Zakat $\rightarrow$ ROE & $\mathbf{1 , 1 4 1}$ & $\mathbf{2 0 , 2 9 4}$ & $\mathbf{0 , 0 0 0}$ \\
Zakat $\rightarrow$ NOM & $\mathbf{1 , 2 0 6}$ & $\mathbf{7 , 0 2 3}$ & $\mathbf{0 , 0 0 0}$ \\
ICSR $\rightarrow$ Rep & $\mathbf{1 , 0 2 8}$ & $\mathbf{4 , 7 5 1}$ & $\mathbf{0 , 0 0 0}$ \\
ICSR $\rightarrow$ ROE & $\mathbf{- 0 , 5 7 6}$ & $\mathbf{- 5 , 8 5 4}$ & $\mathbf{0 , 0 0 0}$ \\
ICSR $\rightarrow$ NOM & $\mathbf{- 1 , 2 4 9}$ & $-\mathbf{4 , 8 1 0}$ & $\mathbf{0 , 0 0 0}$ \\
GGBS $\rightarrow$ Rep & $\mathbf{- 0 , 2 4 0}$ & $\mathbf{- 1 , 2 0 6}$ & $\mathbf{0 , 2 3 6}$ \\
GGBS $\rightarrow$ ROE & $\mathbf{0 , 0 9 9}$ & $\mathbf{1 , 0 9 8}$ & $\mathbf{0 , 2 7 9}$ \\
GGBS $\rightarrow$ NOM & $\mathbf{0 , 3 7 1}$ & $\mathbf{1 , 6 7 1}$ & $\mathbf{0 , 1 0 5}$ \\
\hline
\end{tabular}

\section{Analisis Pengaruh Zakat Terhadap Reputasi}

$\left(\mathbf{H}_{1}\right)$

Hasil pengujian hipotesis pertama menunjukkan nilai signifikansi 0,484 (sig > 0,05) yang berarti bahwa zakat tidak berpengaruh signifikan terhadap reputasi bank umum syariah. Secara teori, zakat yang dibayarkan oleh perusahaan melalui program Corporate Social Responsibility (CSR) akan memberikan signal kepada masyarakat bahwa perusahaan ingin mendapatkan citra yang baik dari masyarakat. Pengungkapan zakat yang konsisten, akan tertanam di pikiran masyarakat yang seiring berjalannya waktu akan meningkatkan kepercayaan kepada perusahaan.

Namun, hasil penelitian ini tidak sejalan dengan teori. Diduga deviasi standar yang cukup besar pada variabel zakat menyebabkan tidak terdukungnya hipotesis pertama. Keberadaan dana pihak ketiga (DPK) juga diduga berpengaruh terhadap tidak terdukungnya hipotesis pertama. Hasil penelitian ini juga tidak sejalan dengan Sidik dan Reskino (2016) yang menyatakan bahwa zakat memiliki pengaruh yang positif dan signifikan terhadap reputasi perusahaan.

\section{Analisis Pengaruh Zakat Terhadap Kinerja $\operatorname{ROE}\left(\mathrm{H}_{2}\right)$}

Hasil pengujian hipotesis kedua (a) menunjukkan nilai signifikansi 0.000 (sig. < 0.05) yang artinya zakat berpengaruh signifikan terhadap terhadap kinerja ROE bank umum syariah. ROE merupakan rasio profitbilitas yang sangat berkaitan dengan kepentingan stakeholder. Tingkat ROE yang tinggi akan mendorong perusahaan untuk menghasilkan keuntungan yang baik sehingga perusahaan dapat memksimalkan penyaluran zakat. Hasil penelitian ini juga sejalan dengan hasil penelitian Sidik dan Reskino (2016) yang menyatakan bahwa zakat memiliki pengaruh yang positif dan signifikan terhadap kinerja perusahaan. Pernyataan tersebut juga didukung dengan hasil penelitian dari Amirah dan Raharjo (2014) yang menyatakan bahwa zakat berpengaruh signifikan terhadap kinerja keuangan perbankan syariah yang juga didukung oleh adanya dana pihak ketiga.

\section{Analisis Pengaruh Zakat Terhadap Kinerja $\operatorname{NOM}\left(\mathbf{H}_{3}\right)$}

Hasil pengujian Hipotesis kedua (b) menunjukkan nilai signifikansi sebesar 0.000 (sig. < 0.05) yang artinya zakat memiliki pengaruh signifikan terhadap kinerja Net Operating Margin bank umum syariah. Net Operating Margin merupakan rasio profitabilitas yang sangat berkaitan dengan kepentingan stakeholder. Tingkat profitabilitas yang tinggi akan mendorong manajemen perusahaan untuk menghasilkan keuntungan yang baik sehingga perusahaan dapat memaksimalkan penyaluran zakat.

Jika dikaitkan dengan teori agency, apabila hubungan antara pemilik dan agen baik, maka zakat dapat meningkatkan kinerja perusahaan. Selain itu, shariah enterprise theory (SET) juga mendukung pernyataan ini bahwa zakat merupakan bukti komitmen yang kuat dari seorang hamba atau entitas yang bertujuan untuk memerhatikan dan mewujudkan keinginan dari para stakeholdernya. Hasil penelitian ini juga sejalan dengan hasil penelitian Sidik dan Reskino (2016) yang menyatakan bahwa zakat 
memiliki pengaruh yang positif dan signifikan terhadap kinerja perusahaan. Pernyataan tersebut juga didukung dengan hasil penelitian dari Amirah dan Raharjo (2014) yang menyatakan bahwa zakat berpengaruh signifikan terhadap kinerja keuangan perbankan syariah yang juga didukung oleh adanya dana pihak ketiga.

\section{Analisis Pengaruh ICSR Terhadap Reputasi $\left(\mathbf{H}_{4}\right)$}

Hasil pengujian hipotesis kedua menunjukkan nilai signifikansi 0.000 (sig. < 0.05 ) yang berarti bahwa pengungkapan Islamic Corporate Social Responsibility pada bank umum syariah berpengaruh secara signifikan terhadap reputasi perusahaan. Diketehui bahwa bank syariah yang memiliki tingkat pengungkapan ICSR yang tinggi, memiliki reputasi yang tinggi pula. Hal ini disebabkan karena bank syariah yang mampu mengadakan dan meningkatkan interaksi dengan konsumen dan para investor. Hasil penelitian ini sejalan dengan Sidik dan Reskino (2016) serta Wardani (2014) yang menyatakan bahwa ICSR memiliki pengaruh yang positif dan signifikan terhadap reputasi perusahaan.

\section{Analisis Pengaruh ICSR Terhadap Kinerja ROE $\left(\mathrm{H}_{5}\right)$}

Hasil pengujian hipotesis kelima variabel ICSR terhadap ROE menunjukkan nilai signifikansi 0.000 (sig. < 0.05) yang menunjukkan bahwa bahwa pengungkapan ICSR berpengaruh signifikan terhadap kinerja perusahaan. Return on Equity (ROE) merupakan rasio yang digunakan untuk mengukur kemampuan bank umum syariah dalam menghasilkan laba yang dikaitkan dengan pembayaran dividen. Jika bank umum syariah memiliki tingkat ROE yang tinggi, maka bank dapat melakukan pengungkapan ICSR yang tinggi.

Hal ini disebabkan karena pengungkapan ICSR sepenuhnya memiliki dampak yang cukup memengaruhi laba pada bank umum syariah. Penelitian ini sejalan dengan Arifin dan Wardani (2016) yang menyatakan bahwa ICSR dapat berpengaruh positif dan signifikan terhadap ROE (kinerja perusahaan). Namun bertentangan dengan Sidik dan Reskino (2016) yang menyatakan bahwa ICSR tidak berpengaruh terhadap kinerja perusahaan.

\section{Analisis Pengaruh ICSR Terhadap Kinerja $\operatorname{NOM}\left(\mathbf{H}_{6}\right)$}

Hasil pengujian hipotesis kelima variabel ICSR terhadap NOM menunjukkan bahwa nilai signifikansi sebesar 0.000 (sig. < dari 0.05). Net Operating Margin (NOM) adalah rasio yang digunakan untuk mengukur kemampuan bank dalam menghasilkan laba yang dilihat dari kemampuan rata-rata aktiva produktif. Jika bank umum syariah memiliki tingkat NOM yang tinggi, maka seharusnya bank dapat melakukan pengungkapan ICSR yang tinggi.

Hal ini disebabkan karena pengungkapan ICSR sepenuhnya memiliki dampak yang cukup memengaruhi laba pada bank umum syariah. Penelitian ini sejalan dengan Arifin dan Wardani (2016) yang menyatakan bahwa ICSR dapat berpengaruh positif dan signifikan terhadap ROE (kinerja perusahaan). Namun bertentangan dengan Sidik dan Reskino (2016) yang menyatakan bahwa ICSR tidak berpengaruh terhadap kinerja perusahaan.

\section{Analisis Pengaruh GGBS Terhadap Reputasi $\left(\mathbf{H}_{7}\right)$}

Hasil pengujian hipotesis ke tiga menunjukkan nilai signifikansi 0.236 (sig. > 0.05) yang berarti bahwa Good Governance Bisnis Syariah (GGBS) tidak berpengaruh signifikan terhadap reputasi bank umum syariah. Good Governance Bisnis Syariah (GGBS) merupakan indikator yang mengatur praktik bisnis syariah yang kuat dan sehat secara finansial dan non financial yang tentunya sesuai dengan prinsip-prinsip syariah. Jika perbankan syariah bisa memaksimalkan pengungkapan ini, maka dengan mudah para pemangku kepentingan, seperti investor dan masyarakat bisa melihat perusahaan dengan kondisi yang baik sehingga tertarik untuk menginvestasikan dananya pada bank umum syariah.

Tidak terdukungnya hipotesis ke tiga pada penelitian ini diduga disebabkan karena masih banyaknya perusahaan yang belum memaksimalkan pengungkapan GGBS sehingga tingkat kepercayaan kepada bank umum syariah pun rendah. Hasil penelitian ini bertolak belakang dengan hasil penelitian Pratiwi (2016)ang menyatakan bahwa kualitas penerapan GGBS pada bank syariah sudah termasuk kategori yang baik dan berpengaruh terhadap reputasi perusahaan.

Analisis Pengaruh GGBS Terhadap Kinerja ROE $\left(\mathrm{H}_{8}\right)$ 
Dalam penelitian ini, untuk melihat pengaruh antara Good Governance Bisnis Syariah (GGBS) terhadap kinerja, dimana kinerja diproyeksikan dengan Return on Equity (ROE). Hasil pengujian hipotesis kedelapan menunjukkan nilai signifikansi 0.279 ( $\mathrm{sig}>$ dari 0.05) artinya bahwa GGBS tidak memiliki pengaruh signifikan terhadap kinerja perusahaan ROE.

Rasio Return on Equity (ROE) merupakan indikator yang penting bagi para pemegang saham dan calon investor untuk mengukur kemampuan bank dalam menghasilkan laba yang dikaitkan dengan pembayaran dividen dan seberapa besar kemampuan rata-rata aktiva produktif dalam menghasilkan laba. Prinsip pemegang saham dalam menginvestasikan dananya pada bank syariah adalah untuk mendapatkan keuntungan yang maksimal. Pemegang saham tidak memiliki hak penuh dalam mengelola manajemen, sehingga manajemen bank umum syariah harus berusaha memenuhi keinginan para pemegang saham dengan melaporkan seluruh kegiatan perusahaan secara transparan.

\section{Analisis Pengaruh GGBS Terhadap Kinerja $\operatorname{NOM}\left(\mathrm{H}_{9}\right)$}

Dalam penelitian ini, untuk melihat pengaruh antara Good Governance Bisnis Syariah (GGBS) terhadap kinerja Net Operation Margin (NOM). Hasil pengujian hipotesis kesembilan menunjukkan nilai signifikansi 0.105 (sig > 0.05) artinya dapat disimpulkan bahwa GGBS tidak memiliki pengaruh terhadap kinerja perusahaan NOM. Net Operating Margin (ROE) merupakan indikator yang penting bagi para pemegang saham dan calon investor untuk mengukur kemampuan bank dalam menghasilkan laba yang dikaitkan dengan pembayaran dividen dan seberapa besar kemampuan rata-rata aktiva produktif dalam menghasilkan laba. Prinsip pemegang saham dalam menginvestasikan dananya pada bank syariah adalah untuk mendapatkan keuntungan yang maksimal. Pemegang saham tidak memiliki hak penuh dalam mengelola manajemen, sehingga manajemen bank umum syariah harus berusaha memenuhi keinginan para pemegang saham dengan melaporkan seluruh kegiatan perusahaan secara transparan.

\section{KESIMPULAN}

Berdasarkan hasil pengujian hipotesis dan mengacu pada perumusan serta tujuan dari penelitian ini, maka dapat ditarik kesimpulan porsi zakat dan pengungkapan Islamic Corporate Social Responsibility berpengaruh signifikan terhadap kinerja Return On Equity dan Net Operating Margin. Hasil penelitian ini menambah bukti empiris bahwa Kinerja yang tinggi akan mendorong perusahaan untuk menghasilkan keuntungan yang baik sehingga perusahaan dapat memksimalkan penyaluran zakat dan memiliki kemampuan untuk melakukan pengungkapan Islamic Corporate Social Responsibility. Namun, penelitian ini gagal dalam memberikan bukti bahwa terdapat pengaruh signifikan atara zakat dan good governance bisnis syariah terhadap reputasi perusahaan. Disamping itu, good governance bisnis syariah juga diketahui tidak mempengaruhi kinerja perusahaan. Hal ini mungkin disebabkan karena pengungkapan good governance bisnis syariah lebih menekankan pada operasional perusahaan, bukan terhadap laba perusahaan yang menjadi indikator dalam mengukur kinerja di penelitian ini. Dalam penelitian berikutnya disarankan agar mempertimbangkan untuk menggunakan indikator maqashid syariah dalam mengukur kinerja dan reputasi perusahaan.

\section{DAFTAR PUSTAKA}

[1] Abas. 2017. Legitimasi \& Politik Kebijakan Teori dan Praktik. Depok: Alta Utama

[2] Amirah dan Teguh Budi Raharjo.2014. "Pengaruh Alokasi dana Zakat Terhadap Kinerja Keuangan Perbankan Syariah". Seminar Nasional dan Call For Paper Program Studi Akuntansi-FEB UMS.

[3] Arifin, Johan dan Eke Ayu Wardani.2016. "Islamic Corporate Social Responsibility disclosure, reputasi, dan kinerja keuangan: Studi pada bank syariah di Indonesia". Jurnal Akuntansi \& Auditing Indonesia.

[4] Ghozali, I. (2013). Aplikasi Analisis Multivariate Dengan Program SPSS. Semarang : BP Universitas Diponegoro Edisi 7

[5] Ghozali, Imam. 2009. Ekonometrika Teori, Konsep dan Aplikasi dengan SPSS 17, 
Badan Penerbit Universitas Diponegoro, Semarang.

[6] Gunawan, Imam. 2017. Pengantar Statistika Inferensial. Jakarta: Rajawali Pers.

[7] Kurniawan, A., \& Suliyanto. (2013). Zakat sebagai aspek terbaru dan pengungkapan islamic social reporting terhadap kinerja keuangan: sebuah agenda penelitian. JOS Unsoed.

[8] Othman R., Thani AM., dan Ghani EK. 2009. Determinants of Islamic Social Reporting Among Top ShariahApproved Companies in Bursa Malaysia. Research Journal of International Studies, issue 12.

[9] Pramesti, Getut. 2014. Kupas Tuntas Data Penelitian dengan SPSS 22. Jakarta: Elex Media Komputindo.

[10] Pratiwi, Angrum. 2016. "Pengaruh Kualitas Penerapan Good Corporate Governance (GCG) terhadap Kinerja Keuangan pada Bank Umum Syariah di Indonesia (Periode 2010-2015)". Al-Tijary Jurnal Ekonomi dan Bisnis Islam, 2016, Vol. 2, No. 1, Hal. 55-76.
[11] Rivai, Veithzal dan Basri, Ahmad Fawzi. 2004. Performance Appraisal: Sistem yang Tepat untuk Menilai Kinerja Karyawan dan Meningkatkan Daya Saing Perusahaan. Jakarta: PT Grafindo Persada.

[12] Sidik.Ichwan, Reskino. 2016. "Pengaruh Zakat dan ICSR terhadap Reputasi dan Kinerja". Simposium Nasional Akuntansi XIX, Lampung.

[13] Sulistyastuti, E. A. (2017). Metode Penelitian Kuantitatif: Untuk Administrasi Publik dan Masalah-Masalah Sosial. Yogyakarta: Penerbit Gava Media.

[14] Syafei, Ade Wirman. 2013. "Analisis Pengaruh Penerapan Good Governance Bisnis Syariah (GGBS) terhadap Kemampulabaan (Studi Perusahaan yang Terdaftar di JII 2011)". Jurnal AL-AZHAR INDONESIA SERI PRANATA SOSIAL, Vol . 2, No. 2, September 2013.

[15] Triyuwono I., 2006. Perspektif, Metodologi, dan Teori Akuntansi Syariah. Jakarta: Rajawali Pers.

[16] Wardani, Eke Ayu. 2015. "Pengaruh Islamic Corporate Social Responsibility Disclosure Terhadap Reputasi Perusahaan dan Kinerja Keuangan Perusahaan”. Jurnal Akuntansi \& Auditing Indonesia. 